\title{
Open Problem-Based Learning (OPBL) Scenario on 2D Text Animation Using Polya Approach
}

\author{
Rahmania Sri Untari *, Vevy Liansari, Firdaus Su'udiah \\ Universitas Muhammdiyah Sidoarjo, Jl. Mojopahit No.666 B, Sidoarjo, 61271 Indonesia \\ rahmania.sriuntari@umsida.ac.id* \\ * corresponding author
}

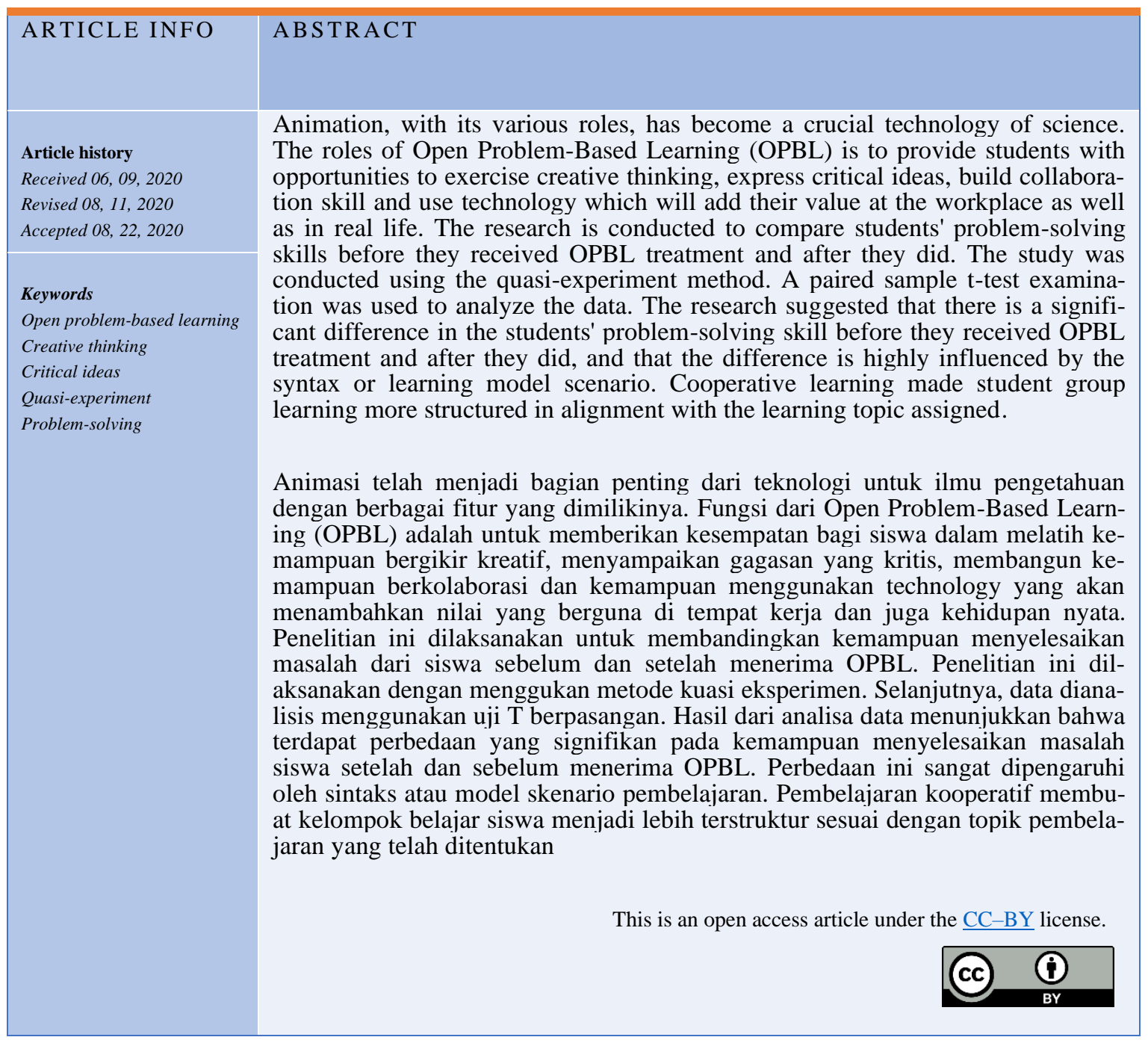

\section{Introduction}

The ability to solve a problem is highly needed by everyone. As suggested by (Holmes, 2005) that individuals with the ability to solve problems lead better lives, are able to make ends meet, create more productive workers, and also understand complex issues regarding the global society so that in a learning process, the emerging problems demand prompt responses from students to solve them. Students who are slow in solving problems will be underachieve ing students and considered to be unproductive throughout their lives (Chu \& Lai, 2002).

OPBL scenario has its variations, but (Jonassen, 2011) suggested that OPBL most common form. The results of (Jonassen, 2011) showed that OPBL (story-problem model) has its weakness in developing real problemsolving skills. Meanwhile, activities in technology (technical and vocational) require individuals to be able to solve problems and identify conflicting limitations, manage several sub- 
problems, communicate, and adapt to unexpected problems.

The result of a study conducted by (Aspinall, 2000) showed that the learning progress of students who used OPBL model increased by nearly $26 \%$ compared to the control school. Besides, there is a significant increase in problem-solving skills between the pretest and the posttest for the experiment class using OPBL model. OPBL can improve students' motivation and provide an image at all levels (Doppelt, 2003). The implementation of OPBL at an early stage can develop students' learning progress, increase students' activity and engagement in learning, nurture creativity and creation, more enjoyable, beneficial, and more meaningful. It is supported by research (Trianto, 2010), which concluded that the application of project-based learning is considerably effective in improving aspects of independence, group cooperation, and psychomotor mastery.

Based on observation on the field, people, in general, are not free from different kinds of problems, both problems related to creating multimedia and issues in day-to-day life. In multimedia classes, students often face challenges in the form of managing frame by frame. Problems highlighted by teachers are problems in real-life so that students are trained to solve problems that require creative thinking. OPBL gives challenges to students, working in a group to solve problems. Those problems are utilized to challenge students in terms of curiosity and initiative to solve a problem. OPBL frequently uses problem-solving as the learning activity and provides students with opportunities to think creatively, express their critical ideas, and communicate their work to their peers. Students have difficulties in solving problems because they are not used to solving problems (Windari \& Dwina, 2014). A condition that results in students' reduced ability to solve problems (Mawaddah \& Anisah, 2015; Widodo \& Kartikasari, 2017). That is, how to provide appropriate learning paths for students in the real world is essential in context-aware ubiquitous learning (Huang et al., 2014).

\section{Method}

\section{Open Problem Based Learning (OPBL)}

Problem Based Learning (PBL) is one of the active learnings. Problem Based Learning (PBL) is an approach which is centered on students and focused on skills, lifelong learning, the ability to apply knowledge, and the skill to solve problems (Tarhan et al., 2008). (Albanese \& Mitchell, 1993; Dolmans \& Schmidt, 2006) suggest that other than equipping students with the knowledge, PBL can also be used to build problem-solving skills, critical and creative thinking skills, lifelong learning, communication skill, group cooperation, adaptation to changes and self-evaluation skill. PBL is designed to provide teachers with as much information as possible to students through a problem (Kamdi, 2012). PBL assists students in developing thinking skills and problem-solving skills, in studying adults and becoming independent learners (Arends, 2013).

Project work is designed as an open-ended contextual activity-based learning. In project work, learners are also socially encouraged into the knowledge construction process, which is part of a learning process that puts a strong emphasis on problem-solving as a collaborative effort (Richmond \& Striley, 1996). The environment of project-based learning provides students with opportunities to learn integrative and multidisciplinary life skills; so that academic competence (which is also called adaptive competence) grows broader and more refined in parallel with technical-productive expertise and employability competence (Bilgin et al., 2009).

(Richmond \& Striley, 1996) state that active learning, such as the OPBL learning model has interactions with significantly bigger higherlevel thinking skills than direct instruction. Fig. 1 shows that the OPBL learning model allows individuals to develop higher order thinking skills such as analyzing, evaluating, and creating.

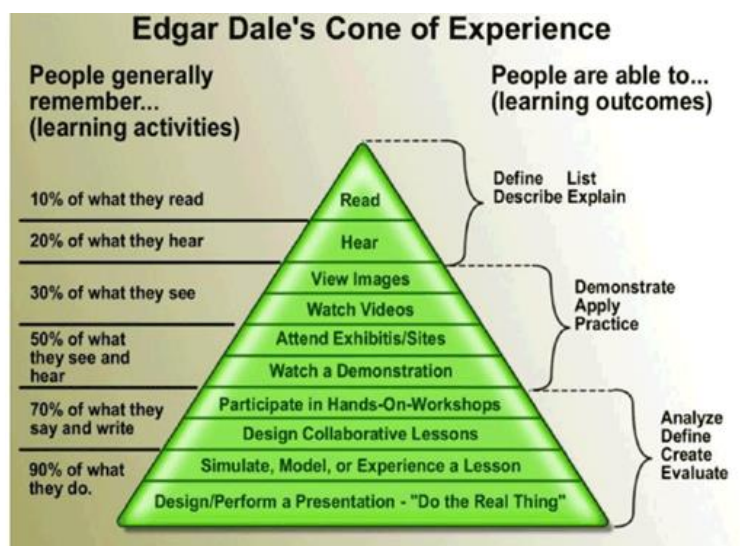

Fig. 1.DEC Theory

\section{A. Polya Approach}

(Polya, 1973) stated that in conducting an assessment to an acquired solution, 4 stages need to be done, including: see (understanding 
the problem), plan (devising a project), do (executing a project), and check (examining the answer). Thus, we can say that problem-solving in creating 2D text animation should follow these steps: (1) defining the goal of the 2D text animation in regard with the problem to be solved (2) collecting data or information which will be used to solve the problem (3) fixing the temporary answer to the problem (4) examining the validity of the temporary solution; and (5) drawing the conclusion. Based on that elaboration, it is concluded that the ability to solve problems requires a high level and complex thinking skill, which involves visualization, imagination, abstraction, and association of information provided. The Polya approach stages are illustrated in Fig 1.

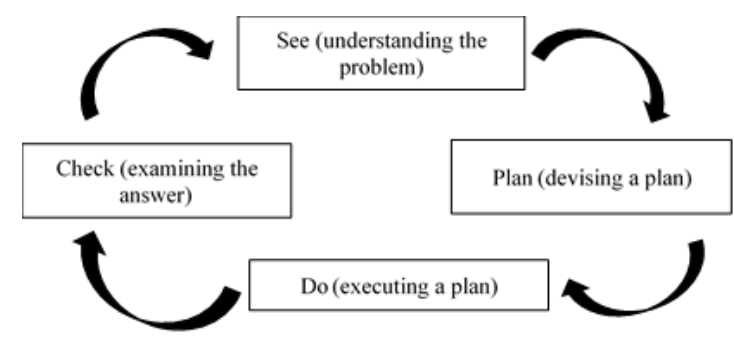

Fig. 2.The Cycle of Polya Approach

\section{B. Research Design}

\section{1) Participants}

The subjects of the experiment were the students of the Information Technology Education program of Sidoarjo Muhammadiyah University. The participants were from one class, with 27 students. Besides, another 1 class was assigned to be an experimental group that learns using the OPBL scenario.

\section{2) Learning procedure}

This research is quasi-experiment. It was selected as there is no way to form a new group as the group has already been formed naturally (Cresswell, 2016). The design used by the research was One Group Pre-Test-Post-Test Design, which is a design where a pretest is conducted before treatment is given, and a posttest after treatment is completed (Cresswell, 2016). The research design used by the researcher is described in Table 1.

Table 1. One Group Pretest-Posttest Experiment Design

\begin{tabular}{l}
\hline $\mathrm{O}_{1} \mathrm{X}$ \\
\hline a. Source: Donald T. Campell dan Julian C. Stanley (1966: 7) \\
Description: \\
O1 $\quad$ : Pretest (preliminary observation) before \\
treatment
\end{tabular}

\section{O2 : Posttest (final observation) after \\ X : Open Project Based Learning (OPBL) treatment}

The obtained data were analyzed using descriptive analysis and assumption testing. Descriptive analysis was conducted to generally determine the mean score of the observed subjects while testing of assumption in this research was carried out by utilizing SPSS with a sig rate of $\alpha 0.05$, which consists of homogeneity and normality testing.

\section{3) Instrument}

The subject of the experiment was the students of the Information technology education program at Sidoarjo Muhammadiyah University. The instrument and data collection techniques used in the research were tests. The data collecting technique was implemented to collect data from the observed subjects. Tests were utilized to measure the ability to solve problems in developing projects and mastery of the material. Table 2 explains the sub-variables to measure the ability to solve problems through 4 stages, consisting of see, plan, do, and check. The content of the problem-solving skill test is described in Table 2.

Table 2. The Content of The Problem Solving Skill Test

\begin{tabular}{|c|c|c|}
\hline No & $\begin{array}{c}\text { Sub Var- } \\
\text { iable }\end{array}$ & Indicator \\
\hline 1 & see & $\begin{array}{l}\text { The student must understand the } \\
\text { condition of the problem in a } \\
\text { particular question, such as: } \\
\text { what data or information is } \\
\text { obtainable in creating basic } \\
\text { animation, text animation, and } \\
\text { motion guide animation; } \\
\text { what is the core of the problem needs } \\
\text { to be solved; } \\
\text { if there are any necessary } \\
\text { requirements that need to be met in } \\
\text { creating basic multimedia animation, } \\
\text { text animation, and motion guide } \\
\text { animation. }\end{array}$ \\
\hline 2 & plan & $\begin{array}{l}\text { The student identifies the pattern of } \\
\text { animation used in deciding the } \\
\text { objects, images, frame by frame } \\
\text { requirement of what will be used, } \\
\text { tools, and so forth. } \\
\text { The student must be able to think of } \\
\text { the necessary and supporting steps to } \\
\text { solve the problem that s/he is facing, } \\
\text { such as in creating multimedia } \\
\text { moving text animation s/he tries to } \\
\text { look into other types of moving ball } \\
\text { animation. }\end{array}$ \\
\hline 3 & do & The student examines each step of the \\
\hline
\end{tabular}




\begin{tabular}{|c|c|c|}
\hline No & $\begin{array}{c}\text { Sub Var- } \\
\text { iable }\end{array}$ & Indicator \\
\hline & & $\begin{array}{l}\text { plan and writes the way to create } \\
\text { multimedia in detail to ensure that } \\
\text { each step is correct } \\
\text { Student executes the steps in the plan } \\
\text { to create multimedia animation }\end{array}$ \\
\hline 4 & check & $\begin{array}{l}\text { The student must try to thoroughly } \\
\text { re-examine and re-evaluate each step } \\
\text { of the solution s/he executed to create } \\
\text { multimedia. } \\
\text { To check the result of the animation } \\
\text { made, s/he can use the tools available } \\
\text { in the flash software. }\end{array}$ \\
\hline
\end{tabular}

Table 3 explains the syntax of OPBL learning scenario applied to the students. Syntax scenario begins before production, defining the strategy, product design, production process, and presentation of the result of the project. The following is the syntax of OPBL scenario.

Table 3. Syntax of OPBL Learning Scenario

\begin{tabular}{|c|c|}
\hline $\begin{array}{l}\text { Syntax } \\
\text { OPBL }\end{array}$ & Description \\
\hline $\begin{array}{l}\text { Before } \\
\text { Production }\end{array}$ & $\begin{array}{l}\text { Students read the question and ensure } \\
\text { themselves that they understand the } \\
\text { question correctly, which is, in this } \\
\text { case, they know the issue of creating } \\
\text { basic animation, text animation, and } \\
\text { motion guide animation. } \\
\text { Students make the multimedia } \\
\text { timeline as instructed by the question } \\
\text { given by the lecturer. }\end{array}$ \\
\hline $\begin{array}{l}\text { Defining } \\
\text { Problem } \\
\text { Solving } \\
\text { Strategy }\end{array}$ & $\begin{array}{l}\text { The workgroups (students) create } \\
\text { proposals by doing literary research } \\
\text { discussions and defining the problem- } \\
\text { solving strategy. } \\
\text { The result of this stage is a } \\
\text { multimedia product created with the } \\
\text { project. The product is in line with the } \\
\text { project theme decided by each group. } \\
\text { The theme covers what is going to be } \\
\text { achieved by the project, what product } \\
\text { is going to be created, and how it is } \\
\text { going to be created. }\end{array}$ \\
\hline $\begin{array}{l}\text { Product } \\
\text { Design }\end{array}$ & $\begin{array}{l}\text { The project is equipped with a design } \\
\text { in the form of multimedia animation } \\
\text { created by each group. }\end{array}$ \\
\hline $\begin{array}{l}\text { Production } \\
\text { Process }\end{array}$ & $\begin{array}{l}\text { It covers the process of creating the } \\
\text { object model. } \\
\text { It includes the process of creating and } \\
\text { coloring and adding textures to the } \\
\text { object being modeled in order to } \\
\text { create a real-life effect. } \\
\text { It includes The process of creating the } \\
\text { multimedia on a frame by frame and } \\
\text { action script. }\end{array}$ \\
\hline $\begin{array}{l}\text { Presentation } \\
\text { of Project } \\
\text { End-Result }\end{array}$ & $\begin{array}{l}\text { The presentation is aimed actually to } \\
\text { communicate the creation or the } \\
\text { invention of multimedia animation, } \\
\text { through class seminars, each group } \\
\text { presents their work. }\end{array}$ \\
\hline
\end{tabular}

Fig. 3 is a project made by a group of students, which is making a track car and lunar orbit around the sun.

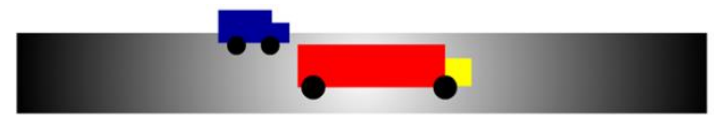

Fig. 3.OPBL Track Project

\section{Experimental results}

The OPBL effectivity test in solving problems was conducted on 1 group of students from the experiment class. The researcher conducted an experiment with pretest-posttest design with the objective of determining the effect of PJBL on the ability to solve problems of the students. The data analysis was performed using an independent sample t-test. Fig. 1 shows the strength of solving problems of the students who were randomly selected to be the experiment group of 27 persons.

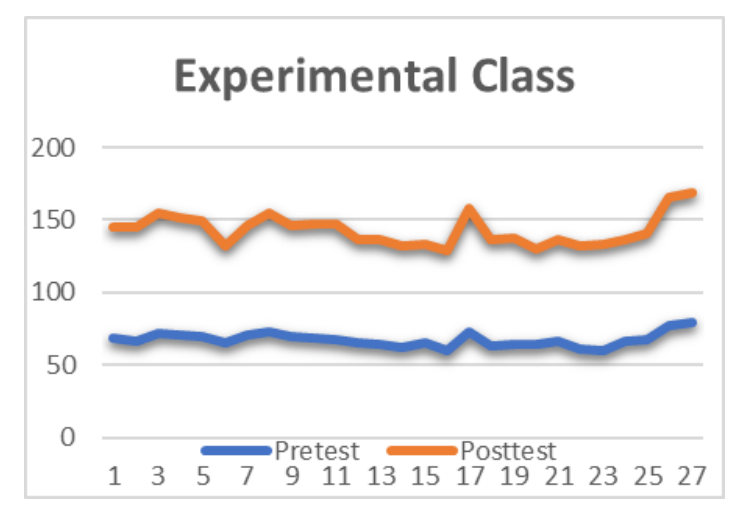

Fig. 4. The Ability to Solve Problem of Students

Fig. 1 showed a graphic of the students' ability to solve problems based on the pretest score and the posttest score. Based on the pretest, the average score is 67.52 , the deviation standard 4.83, the lowest score 60.00 , and the top score 79. Based on the posttest, the average score is 75.48 , the deviation standard 6.29 , the lowest score 66.00, and the top score 90.00 .

Before testing the hypothesis with a paired sample t-test, it is necessary to conduct a normality test and homogeneity pre-requirement. Data normality was determined by the ShapiroWilk test as the number of samples is under 50. The Shapiro-Wilk value based on the pretest score is 0.96 with sig. $=0.58$, and the ShapiroWilk value based on the posttest score is 0.95 with sig. $=0.29$. Because of the sig. $>0.05$, it was concluded that the data of the two groups were normally distributed. For the homogeneity test, the homogeneity of variance test showed a sig. value of 0.13 , larger than 0.05 . Thus, it was 
concluded that the data variance of the two groups of students was homogenous.

After the pre-requirement test, hypothesis testing was conducted to identify any difference in the ability to solve the problem by utilizing a paired sample t-test. The results of the test are presented in Table 4.

Table 4. The Result of Paired Sample t-test Analysis

\begin{tabular}{ccccc}
\hline Score & N & SD & Mean & t-test \\
\hline Pretest & 27 & 4.83 & 67.52 & $-12.58(0.000)$ \\
\hline Posttest & 27 & 6.29 & 75.48 & $-13.54(0.000)$ \\
\hline
\end{tabular}

Based on Table 4, sig. of 0,000 is less than 0,05 , which means there is a significant (real) difference in the ability to solve problems before the treatment is given and after the procedure is performed. A learning process with OPBL scenario students can improve their ability to solve multimedia problems, which develop them to be a more active and independent learner.

\section{Results and Discussion}

Based on the findings of this research, it is suggested that the application of OPBL scenario has a significant effect on improving the students' ability to solve problems of multimedia animation-based learning. The finding is in line with the research that stated that the OPBL model is more advanced in increasing students' ability as the syntax of the model is systematically designed based on the learning hierarchy (Gómez-Pablos et al., 2017). Based on the pretest and posttest scores, it is apparent that the improvement of the scores is still considered minor. It is caused by the absence of equality between students and their lecturer. Both parties should work on solving problems together and engage more in two-way discussions so that students feel empowered, confident and motivated, which would result in an optimized understanding of a subject compared to the conventional lecture (Pérez et al., 2009). In line with the findings of (Slunt \& Giancarlo, 2004) which stated that the OPBL model that focuses on the students provides them with the opportunity to decide for themselves how far they are going to learn.

In order to develop an OPBL model scenario to optimize the results, it requires equality between students and their lecturer by increasing two-way communication so that in the learning process, students would not find any obstacle in finding a solution to a problem. In the OPBL model, students are given the freedom to explore issues in the field. In OPBL model scenario, it is not sufficient to have one single solving procedure considered to be more advanced, but problems require alternative answers and compelling arguments to support the solution (Hmelo-Silver \& Barrows, 2006).

(Jalinus et al., 2019) found that in OPBL model, learning activities are directed toward project assignment, while students' learning activity begins with the motivation to achieve progress, which is made available by a module through cooperative learning, conceptual understanding, and work principles through learning media, prototypes, discussions, and demonstrations. Cooperative learning makes students' group learning more structured following the learning topic assigned (Saripudin et al., 2015). In the process of finding a solution, (Jonassen, 2011) mentioned that the OPBL model does so in 5 stages, namely: (1) before production, (2) defining solving strategy, (3) designing product, (4) production process, 5) presentation of end-result.

OPBL model is a combination of two learning models, cooperative learning, and projectbased learning (Jalinus et al., 2019). First, students learn to understand theory through cooperative learning, and then they work on project assignments applicating project-based learning models (Ana \& Nurlaela, 2012). The OPBL model treatment at the beginning of the learning process has a significant influence on the students' ability to perform project assignments. Students are confident with their ability to solve different kinds of problems emerging during designing, selecting, drawing, and calculating their project assignments in a group or individually (Arcidiacono et al., 2016).

Meanwhile, students complete their projects directly in the application of OPBL model. They tend to be unsure, doubtful, spending too much time reading and looking for information, in both group discussions and consultations (Baser et al., 2017). When they are facing a problem, they have to think of a solution and call for assistance through discussions and consultations with the lecturer (Yevdokimov \& Passmore, 2008). In this regard, when the lecturer assists them, much of the solution comes from the lecturer. Thus, OPBL is useful to improve students' ability to solve problems, particularly in creating multimedia animation. 
The learning tools that need to be prepared by a lecturer when applying OPBL model are (1) the lecturer prepares a scenario design or makes OPBL project framework in delivering the information needed by the students; (2) the lecturer prepares a practice module as the learning media; (3) the lecturer decides project topics of student groups; (4) the lecturer provides assistance to students while the learning activity is taking place; and (5) the lecturer evaluates the end-result/work of each student group.

In OPBL model, students also need to be given requirements so that they develop applicative skills and employable because as they are completing their study in university, they are trained to solve real-world problems. (Douglas et al., 2012; Severin \& Tankard, 2011) suggest the importance of giving structured instruction to students in the skill of collecting information to solve problems. A structured instruction of finding information helps students to build their knowledge more accessible and faster.

Based on the explanation above, it is concluded that OPBL learning model improves the ability to solve problems through different topics assigned. The design of OPBL scenario, which is open-ended in nature, is compatible with the characteristic of the field of technology, which reflects the realistic complexity and uncertainty. OPBL learning model provides students with the opportunity to look at problems environment from different perspectives to enhance their high order thinking (HOT) skills ability. The opinion is supported by (King et al., 2013), stating that HOT is activated when individuals encounter unfamiliar problems.

\section{Conclusion}

Based on the results of the study, it can be concluded that the OPBL learning scenario can improve the students' problem-solving abilities in making multimedia animation. It requires constructive learning strategies to apply OPBL effectively in class, namely: a) collaborative learning strategies, b) prioritizing student activities rather than lecturer activities, d) experience at the time of practicum, and e) problemsolving. These findings can be inputs for educators to innovate the teaching and learning process. One of the innovations is developing learning models to improve students' understanding of skills in solving problems.

\section{Acknowledgment}

The sincerest gratitude is addressed to the Directorate of Research and Community Ser- vice (DRPM) Universitas Muhammadiyah Sidoarjo (UMSIDA) for the support of information, policy, and fund so that this research can be finished well.

\section{References}

Albanese, M. A., \& Mitchell, S. (1993). Problembased learning: A review of literature on its outcomes and implementation issues. Academic Medicine, 68(January), 52-81.

Ana, A., \& Nurlaela, L. (2012). Development model of patisserie project-based learning. Journal of Technical Education and Training, 4(2).

Arcidiacono, G., Yang, K., Trewn, J., \& Bucciarelli, L. (2016). Application of axiomatic design for project-based learning methodology. Procedia CIRP, 53(2016), 166-172.

Arends, R. I. (2013). Belajar untuk mengajar, learning to teach. Salemba Humanika.

Aspinall, E. T. (2000). Political opposition and the transition from authoritarian rule: The case of Indonesia. The Australian National University.

Baser, D., Ozden, M. Y., \& Karaarslan, H. (2017). Collaborative project-based learning: An integrative science and technological education project. Research in Science \& Technological Education, 35(2), 131-148.

Bilgin, I., Şenocak, E., \& Sözbilir, M. (2009). The effects of problem-based learning instruction on university students' performance of conceptual and quantitative problems in gas concepts. Eurasia Journal of Mathematics, Science and Technology Education, 5(2), 153-164.

Chu, K. C., \& Lai, P. (2002). How can engineering students' problem solving skills be improved? World Transactions on Engineering and Technology Education, 1(1), 91-94.

Cresswell, J. (2016). Research design: Pendekatan metode kualitatif, kuantitatif, dan campuran (4th ed.). Pustaka Pelajar.

Dolmans, D. H., \& Schmidt, H. G. (2006). What do we know about cognitive and motivational effects of small group tutorials in problem-based learning? Advances in Health Sciences Education, 11(4), 321.

Doppelt, Y. (2003). Implementation and assessment of project-based learning in a flexible environment. International Journal of Technology and Design Education, 13(3), 255-272.

Douglas, E. P., Koro-Ljungberg, M., McNeill, N. J., Malcolm, Z. T., \& Therriault, D. J. (2012). Moving beyond formulas and fixations: solving open-ended engineering 
problems. European Journal of Engineering Education, 37(6), 627-651.

Gómez-Pablos, V. B., Del Pozo, M. M., \& Muñoz-Repiso, A. G. V. (2017). Projectbased learning (PBL) through the incorporation of digital technologies: An evaluation based on the experience of serving teachers. Computers in Human Behavior, 68(March), 501-512.

Hmelo-Silver, C. E., \& Barrows, H. S. (2006). Goals and strategies of a problem-based learning facilitator. Interdisciplinary Journal of Problem-Based Learning, 1(1), 21-39.

Holmes, D. (2005). Communication theory: Media, technology and society. Sage.

Huang, Y. M., Liao, Y. W., Huang, S. H., \& Chen, H. C. (2014). A jigsaw-based cooperative learning approach to improve learning outcomes for mobile situated learning. Educational Technology \& Society, 17(1), 128-140.

Jalinus, N., Syahril, S., \& Nabawi, R. A. (2019). A comparison of the problem-solving skills of students in $\mathrm{PjBL}$ versus $\mathrm{CPjBL}$ model: An experimental study. Journal of Technical Education and Training, 11(1), 036-043.

Jonassen, D. H. (2011). Design problems for secondary students. In National Center for Engineering and Technology Education (p. 6). ERIC

Kamdi, W. (2012). Implementasi project-based learning di sekolah menengah kejuruan. Jurnal Pendidikan Dan Pembelajaran (JPP), 17(1), 98-110.

King, F. J., Goodson, L., \& Rohani, F. (2013). Higher order thinking skills, publication of the learning and assessment.

Mawaddah, S., \& Anisah, H. (2015). Kemampuan pemecahan masalah matematis siswa pada pembelajaran matematika dengan menggunakan model pembelajaran generatif (generative learning) di SMP. Edu-Mat: Jurnal Pendidikan Matematika, 3(2), 166-175.

Pérez, E., Penarrocha, I., Pérez, A., Serrano, J., Belenguer, E., \& Sanchis, R. (2009). Cooperative project-based learning for machine design in the Industrial Engineering Program: Methodologies and experiences. Technology, Education and Development, 395, 414.
Polya, G. (1973). How to solve it, nueva jersey, estados unidos. Princeton University Press.

Richmond, G., \& Striley, J. (1996). Making meaning in classrooms: Social processes in small-group discourse and scientific knowledge building. Journal of Research in Science Teaching: The Official Journal of the National Association for Research in Science Teaching, 33(8), 839-858.

Saripudin, A., Haryani, S., \& Wardani, S. (2015). Characterized Project based learning to improve critical thinking skill. International Conference on Mathematics, Science, and Education (ICMSE 2015).

Severin, W. J., \& Tankard, J. W. (2011). Teori komunikasi: sejarah, metode dan terapan didalam media massa (5th ed.). Kencana.

Slunt, K. M., \& Giancarlo, L. C. (2004). Studentcentered learning: A comparison of two different methods of instruction. Journal of Chemical Education, 81(7), 985.

Tarhan, L., Ayar-Kayali, H., Urek, R. O., \& Acar, B. (2008). Problem-based learning in 9th grade chemistry class:'Intermolecular forces.' Research in Science Education, 38(3), 285-300.

Trianto, M. P. (2010). Mendesain model pembelajaran inovatif-progresif: Konsep, landasan dan implementasinya pada Kurikulum Tingkat Satuan Pendidikan (KTSP). Jakarta: Kencana.

Widodo, S., \& Kartikasari, K. (2017). Pembelajaran pemecahan masalah matematis siswa sekolah dasar dengan model creative problem solving (CPS). Prisma, 6(1), 57-65.

Windari, F., \& Dwina, F. S. (2014). Meningkatkan kemampuan pemecahan masalah matematika kelas viii SMPN 8 Padang tahun pelajaran 2013/2014 dengn menggunakan strategi pembelajaran inkuiri.

Yevdokimov, O., \& Passmore, T. (2008). Problem solving activities in a constructivist framework: Exploring how students approach difficult problems. Proceedings of the 31st Annual Conference of the Mathematics Education Research Group of Australasia (MERGA 31), 2, 629-636 